E3 Journal of Business Management and Economics Vol. 11(1). pp. 001-009 February, 2021 Available online http://www.e3journals.org

ISSN 2141-7482 (C) E3 Journals 2021

DOI: http://dx.doi.org/10.18685/EJBME(11)1_EJBME-21-011

Review

\title{
Resolving the disconnect between market actors, agents and brokers and small-holder fresh produce farmers in Agribusiness
}

\author{
P. Mburu \\ Department of Marketing, University of Botswana; Email: mburupt@ub.ac.bw
}

Accepted $4^{\text {th }}$ February, 2021

Farming contributes a good portion of African GDP and employs a substantial percentage of Africa's labour force. African farming is characterised by smallholder farmers who sell to market actors' agents and brokers. As a result, farmers complain of low returns on investments and cartel behaviour which discourage younger generation in venturing into farming or taking farming as business. The objective of this paper is to review the literature and suggest a model that could address the disconnect, based on the collective entrepreneurship theory.

Keywords: small-holder farmers, market actors' agents and brokers, cartel behaviour, collective entrepreneurship theory, African farming, agri-business, agro-food chains

\section{INTRODUCTION}

The importance and use of Market actors, Agents and Brokers in agro-value chain has become evident in Africa as urbanisations and economic growth increase (Brondízio et al., 2002). These agro-food chains and networks play an increasingly important role in providing access to markets for producers especially in developing countries. Globalization of trade and integration of supply chains leads to new demands regarding food quality and safety (Ruben et al., 2006). The growth in agroprocessing has triggered development in other sectors of the economy through multiplier effect. It has created jobs away from farms in towns and city factories as well as in other sectors such as transportation, distribution, and retailing, among others. The adequacy supply to agro-processing, towns and city markets call for Market actors, Agents and Brokers on the agrofood chains especially for small-holder fresh produce farmers. Apart from the forward linkages such as processing and marketing agro-processing Market actors, Agents and
Brokers help to create backward linkages by supplying credit, input and other services to primary producers.

However African framers, being small scale, rural based and poor, have often had negative perception of Market actors, Agents and Brokers, mainly due to the low prices, and unfair treatment they receive (Poole, 2017; Kamau, 2019; Mburu, 2020; Ohashi, 2020; Hersi, 2020). Given the importance of the Market actors, Agents and Brokers in the agro-marketing strategy, this paper endeavours to look at the literature to try and uncover the disconnect between the importance of the Market actors, Agents and Brokers and suggest strategic and policy changes that could transform them from perceived cartels to agro-value-chain for smallholder fresh produce farmers in Africa.

The importance of agri-business in Africa cannot be downplayed. Agriculture employ's an average of $58 \%$ of African labour force (ILO, 2019; Poole, 2017). With the world population expected to swell by two billion people over the 
next three decades, Africa's agricultural sector is possibly the continent's biggest growth lever, with a the potential to meet not only its own food requirements, but also to feed greater world population, and by so doing creating muchneeded jobs, considering that Africa is estimated to hold about $60 \%$ of the world's uncultivated arable land.

\section{Objective and methods of the study}

According to (Jari and Fraser, 2009), Markets are important because they act as a mechanism for exchange. They are particularly important to the small-holder farmers, because their involvement in the use of markets results in coordination and allocation of resources, goods and services, thus reducing poverty and improving livelihoods of households. The objective of this paper is to looks at the literature, with aim of identifying the underlying challenges that small-holder fresh produce farmers face with the Market actors, Agents and Brokers, which makes them to be viewed as oppressive cartels rather than as an important agro-value chain and to suggest an appropriate model where African smallholder fresh produce farmers can benefit from agribusiness.

\section{Theoretical framework}

The paper is informed by the collective entrepreneurship theory suggested by RibeiroSoriano and Urbano (2009), Toledano et al. (2010) and Mudiwa (2017). Mudiwa (2017), suggests that access to markets being one of the most difficult challenges that small-holder fresh produce farmers face, the role of collective entrepreneurship in helping farmers gain economies of scale is vital. Through collective entrepreneurship, farmers can attract traders and buyers, and can increase their negotiating power. Thus, collective entrepreneurship is considered as an appropriate tool for linking small-holder fresh produce farmers to markets thereby upgrading their socio-economic status. According to Mudiwa (2017), collective entrepreneurship is defined as a form of rentseeking behaviour exhibited by formal groups of individual agricultural producers that combine the institutional frameworks of investor-driven shareholder firms and patron-driven forms of collective action. He argues that for any form of collective organization to achieve the highest performance, members' decisions about their own on-farm activities and investments should be aligned with that of the cooperative.

A strong marketing orientation within any organization is considered a necessity in creation of a competitive advantage. The performance of marketing strategy is gauged on its positive impact on the company's or organisational performance. This is more so in agro- business. The use of market actors, agents and brokers in agro-marketing has become a major strategic consideration for most of the agri-business. According to Asliddin and Suxrob, (2015), agricultural marketing focuses on policy, distribution channel, and efficiency issues. Unlike the general product, agromarketing has not evolved with a marketing management orientation. It focuses mainly on the services involved in efficiently moving agricultural products from the farm to the consumer. Marketing orientation on the other hand goes father to ensure internal and external customer orientation by establishment of relationships.

\section{Importance of fresh produce production in Africa}

In Africa, the agricultural sector is the backbone of national economy, contributing between 15\% and $40 \%$ of Gross Domestic Product (GDP), $75 \%$ of employment and $60 \%$ of the export earnings (Diao et al., 2010; Moyo, 2016). According to Garcia et al. (2018), fresh produce production has emerged as one of the leading sub-sectors in kenya in terms of foreign exchange earnings, food security, employment creation, and poverty alleviation. Agricultural production accounts for one third of the kenya's GDP and is the primary source of livelihood for the majority of rural households. Agriculture employs 38 per cent of the total labour force and $73 \%$ of the rural population labour force. It supplies manufacturing sector with about $75 \%$ of industrial raw materials thus generating tax revenue and foreign exchange that supports other economic activities.

The fresh produce is dominated by smallholder growers who constitute about $80 \%$ and produce about $55 \%$ of the total exports. According to African Development Fund Report (2007), The Kenyan area under horticulture crops increased from 226,989 ha in 1998 to 403,749 ha in 2005 which is mainly attributed to 
the expansion of vegetable cultivation from 91,297 ha to 245,660 ha, a $(269 \%)$ increase. The fresh produce production constituted an estimated production of 2.5 million tonnes of vegetables in 2005, with Irish potatoes constituting about $39 \%$, cabbages $21 \%$, tomatoes $14 \%$, kale $13 \%$, onions $3 \%$ while bananas accounted for $54 \%$. This data is easily replicated in most sub-Saharan African countries. However, according to Emongor (2009), most of the fresh produce is sold through the merchant market-actors due to factors which make it difficult for small-holder fresh produce farmers to access and supply to supermarkets. For Supermarkets to remain competitive and survive they set high quality standards for their products and offer low prices to consumers. Fresh fruit and vegetable farmers may need to invest in cold storage and transport facilities in order to deliver produce of high quality and on time, to supermarkets or central buying centres. As a result of procurement practices and policies, many small-holder fresh produce farmers are potentially excluded from these emerging urban and rural markets unless they can adapt to these changes which in turn forces them to deal with merchant marketactors, whose main objectives differ from the farmers.

\section{Categories of merchant market actors}

According to Imam et al. (2014), six classes of middlemen have been identified some of them with overlapping functions. A Kenyan agribusiness encounters ana average of eight market actors upstream before good can reach the consumer. These are: - loaders at the farm, transporters, off-loaders at the market, in-market stall agents, market security agents and market licences officers, the wholesalers, and the retailers (Mburu, 2020). Eskola (2005), while looking at Agricultural marketing and supply chain management in Tanzania also noted eight intermediaries including the transporters of the Supply Chain of Agricultural Products from Regions into Dar es Salaam Market. This resulted to minimal returns to the farmers compared to the retail price paid by consumers. These classes of middlemen are:

- Farm gate middlemen

- The non-commissioned agents

- The cooperative marketing agency

- The wholesaler

- The retailer

\section{Importance of market actors, agents and brokers}

African agricultural food markets lack collective marketing and collective purchasing. There are long distances between production areas and consumption areas, coupled with poor infrastructure facilities, inadequate storage facilities and marketing strategies, especially at the producer level. This makes it necessary for a fresh produce small holder farmer to sell the products raw, to avoid rotting (Chiuri et al., 2013). Thus, most sales are done at harvest time, when prices are at their lowest. Smallholder farmers face poor access to credit, markets and market information. Buxton (1979), Imam et al. (2014), listed five gaps evident in agro-marketing that make small-holder fresh produce farmer's use of merchant market-actors necessary. These are: - (i) Time gaps; consumers purchase items at discrete intervals. (ii) Space gaps; consumers are dispersed geographically whereas producers are in few areas of rural farms. (iii) Quantity gaps; economic reasons make firms produce large quantity, while the middlemen buy and sell in the quantities required by consumers. (iv) Communication and information gaps; consumers may not know the sources of the goods they want, and producers may not know the potential purchaser of his produce.

According to Imam, Imam et al. (2014), agroproduce often change hands up to six times before reaching the consumer depending on the produce in question. For fresh produce such as fruits and vegetables, a minimum of five transactions is often involved, with the consumers buying from retailers after the commodity have passed from producers through the hands of farm collecting agent, market assemblers and wholesalers. This chain makes the returns enjoyed by the small-holder fresh produce farmers pale, compared to the price paid by the consumers.

According to Appel et al. (2014) Market actors, Agents and Brokers are a necessity in agro-marketing value chain. They comprise of all intermediaries who mediate in the value chain process. Intermediaries can be commissioners (brokers, commission agents) or merchants. Commission agents arrange purchasing agreements between producers and traders (e.g. merchants or retailers) on behalf of the farmers, without owning the produce. In contrast, merchants take the ownership and re-sell the products in their own 
name. The merchants often perform value adding processes like cleaning, sorting, packing or labelling of the produce. Demirbaş (2005), noted that market actors, agents and brokers play a major role in the value chain which farmers and the market cannot do without. In most African countries, unfavourable trade policies and/or lack of enforcement of the existing ones exacerbate the problems, which affect traders and spill over to the farmers.

Small scale farmers cannot adequately adapt to newly emerging market demands and rework their business. The weak power position of the farmers together with the high degree of competition in the market, make it almost mandatory for farmer to rely on market actors, agents and brokers (Appel, Franz, and Hassler, 2014). Farmers have no control mechanism that enables them to engross in the negotiation process between commissioners and buyers. They therefore must rely on the information provided by the market actors, agents and brokers which underlines the role of trust in such networks and leads to an information advantage and a considerably high power of the market actors, agents and brokers over the farmers.

\section{Factors contributing to market actors, agents and brokers cartel tag}

The use Market actors, Agents and Brokers has not always resulted in sound marketing strategy for agro- marketing chain especially at the farm level (Duffy, 2005). This is mainly because the objectives of marketing vary. Olwande et al. (2015), noted that several factors hinder commercializing of smallholders which is one of the most effective ways of agro-marketing that can stimulate rural economies especially in Sub-Saharan Africa (Belaineh, 2002), these include:

Farmer characteristics: Production and market risks as well as factors such as farm size, proximity to markets, roads and agroecological conditions, hinder most small scale farmers from accessing the market or accessing the right market (Antwi and Seahlodi, 2017). The lack of quality extension services for the farmers in order to equip them with important production and marketing skills and the supply of useful marketing information has also hindered the marketing of agro-produce to the benefits of the African farmers. Molony (2008), noted that most farmers often lack credit to purchase agricultural inputs, and rely on their buyers to provide it, irrespective of the price. Some other strategic marketing problems agrobusiness or farms, face relates to competition, logistics, sound decision making due to insufficient and timely information (Shiferaw et al., 2008; Rossi et al., 2014). The state policies and interventions such as example, local taxes, restrictions on cross-border trade, reduce the profitability of private sector trading activity and/or lower the prices ultimately received by producers. The market liberalisation has coincided with a sharp decline in state budgets and hence in public investment in key public good, such as research, extension and infrastructure, hampering agro-production and marketing. Low infrastructural development leads to high transaction costs and risks in agricultural marketing (Poulton, Kydd, and Dorward, 2006). To fill this gap merchants market-actors find an opportune business window that provides a good returns on investments to the detriment of the African farmers.

Market related factors: According to Chiciudean et al. (2015), agro-food companies are more sales - oriented than marketing oriented when facing the market, which on medium and long term could have negative impact on companies' performance. Bignebat et al. (2009), noted that small farms have been found to suffer under diseconomies of scale in producing quality because they cannot invest in capital, specific practices, and organization of production. As the market changes, local farmers are facing increasing market competition, not only in international markets, but in local markets as well. To withstand the market pressures, agricultural markets are now transforming to a vertically coordinated structure (Jari and Fraser, 2009) of which, penetrating this structure as a small farmer becomes almost impossible.

Moreover, the budgetary and liquidity constraints of smallholder fresh produce farmers do not allow them to invest and adapt to the market demands. Some markets especially the European and Chinee's supermarkets require high levels of quality and traceability of which the small-scale farmers cannot cover the transaction, supervising and monitoring costs or the production process in order to access these remunerative markets (Antwi and Seahlodi, 2017). In some cases, the quantity required, is so high such that farmers searching for a 
business partner, who can guarantee the quality level of the delivered produce, or enforcing agreements becomes almost impossible. Being at the level of the individual smallholder, Producers usually carry out some or all the marketing steps. Often, because producers are also consumers, little of what is produced is marketed at the right price. Most agri-Business owners may be only marginally market oriented. Because of traditional attitudes towards farming, small-holder fresh produce farmers choose to sell at lower prices rather than to hold and market the produce when the price improves.

Product related factors: according to Karthikeyan (2016), the marketing of agricultural commodities is different from the marketing of manufactured commodities because of the special characteristics. The special characteristics which make agricultural products risky to sell are: 1 . Perish ability of the Product: Most farm products are perishable in nature; but the period of their perishability varies from a few hours to a few months (Appel et al., 2014). 2. Seasonality of the farm products which are produced in a season; and consumed throughout the year. In the harvest season, prices fall as every farmer need to offload the product to market, while it increases when products are out of the season (Chiuri et al., 2013). Their prices of manufactured goods however remain almost the same throughout the year. 3. Bulkiness of almost all farm products makes their transportation and storage difficult and expensive. These facts also restricts the location of production to somewhere near the place of consumption or processing. The price spread in bulky products is higher because of the higher costs of transportation and storage (Shiferaw et al., 2008; Imam et al., 2014). 4. Variation in Quality of agricultural products, which makes their grading and standardization somewhat difficult. 5. Irregular Supply of Agricultural Products because of the dependence of agricultural production on natural weather conditions. With the varying supply, the demand remaining almost constant, the prices of agricultural products fluctuate substantially (Imam et al., 2014). 6. Small size of holdings and scattered production throughout the length and breadth of the country with most of the producers being of small size (Poole, 2017). 7. Most of the farm products must be processed before their consumption by the ultimate consumers which increases the price spread of agricultural commodities, (Antwi and Seahlodi, 2011)

Technology related factors: According to Jari and Fraser (2009), small-holder fresh produce farmers are still lagging in the use of improved technology. They lack appropriate transportation facilities and road infrastructure, communication links and storage infrastructure. Further, smallholder farmers have limited ability to add value to their produce, according to Mandal (2019), while significant developments in terms of infrastructure in other sectors has been achieved, the support in the agribusiness sector is sub-par and lacking behind most of the economies. Connectivity Network is the heart and soul of any digitization process. It is unfortunate that despite having the large number of internet users in Africa, connectivity is a significantly low and slow in most of the rural parts. At the same time due to the nature of the small holder fresh produce farmers, it takes a considerable time to make farmers switch to modern farming and communicating practices since they are not willing to shift to newer marketing technology and channels. The underlying inferences behind this, is that most fresh produce farmers are not able to market their products themselves and have to rely on merchant middlemen and agents of whom they have a long working relationship with, even though the latter gains more and eats up a huge profit of the former.

\section{Marketing of fresh produce model}

Steps to address this disconnect between the important services provided by Market actors, Agents and Brokers, marketing strategy and Policy intervention in the 'supply chain coordination' include (See Figure 1 also).

Policy Change: The policy change involves the development of an effective system to support co-ordinated, complementary decision-making by different players across a supply chain to the benefit of the fresh produce farmer. Mittendorf (1989), noted that it is necessary to strengthen macro policy changes, with reference to fresh produce marketing policies, with the objective of providing more incentives to marketing enterprises and local authorities in order to promote infrastructure development. He argued that changes in macro policies must be supported by adequate training programmes. 


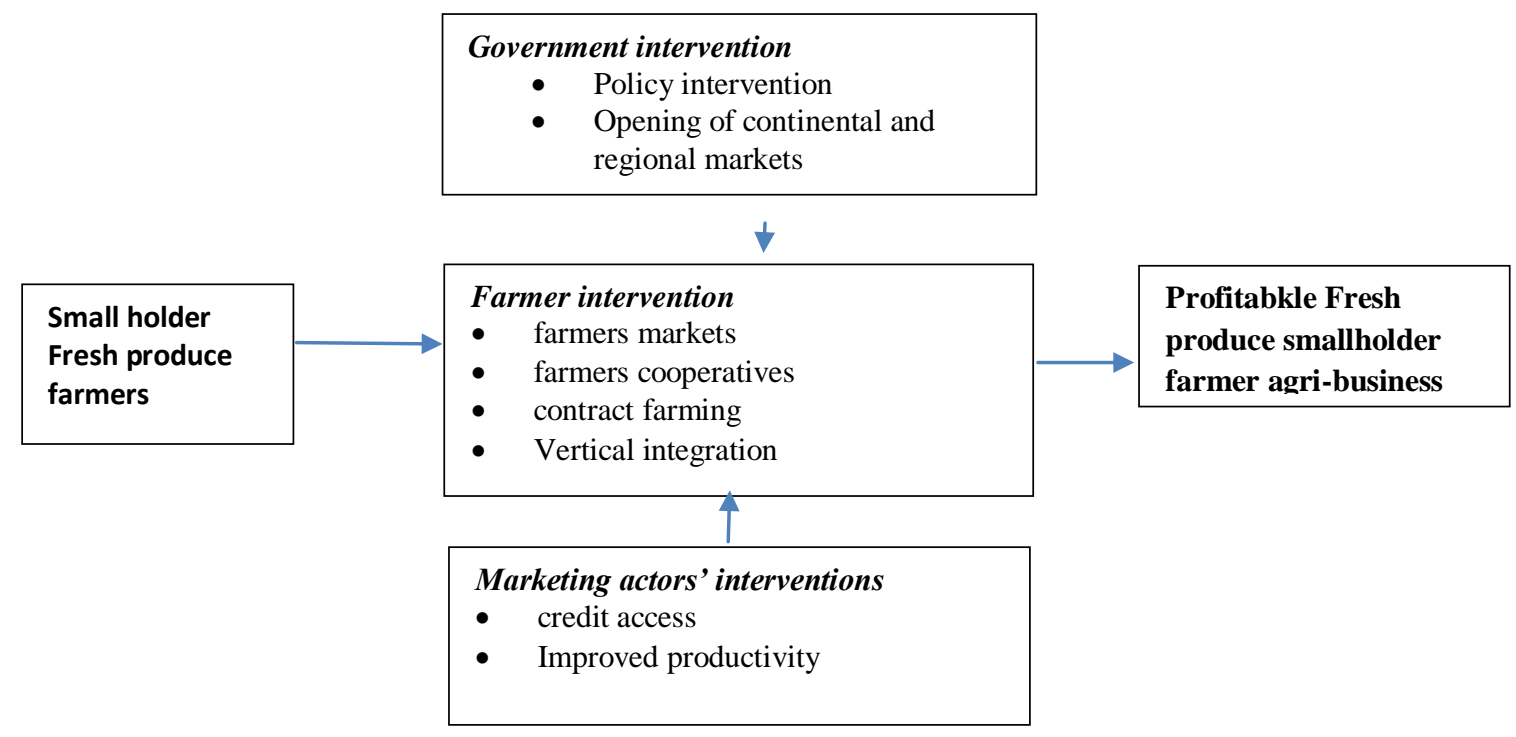

Figure 1. Policy intervention in the 'supply chain co-ordination'

Support to institution building and adjustment of aid strategies would encourage self-help in developing marketing infrastructure for smallholder fresh produce farmers.

Establishment Of Farmers Markets: Mburu (2020), noted that an establishment of farmers markets where farmers can deliver straight to the retailer shortens the value chain between the farmers and consumer would increase the farmers income by about $60 \%$. The contact between the farmer and the retailer helps not only in increasing returns for the farmers but also in determining the market needs to ensure farmers grow what will sell.

Credit access: Credit access is vital for African farmers. Most farmers in Africa are mobilephone connected and banked and as such (Molony, 2008; and Wanzala, 2019) suggested that a more open system than currently exists in, mobile-payment ('m-payment') applications should target creditor-buyers as key agents in connecting farmers to the credit they so often require. This will ensure farmers are not held captives by the merchant market actors who provide inputs and credit to farmers. According to Poulton et al. (2006), there has been considerable discussion of the growth of informal financial institutions serving the poor, including savings and credit co-operatives (SACCOs), and Credit Associations (ROSCAs), Accumulating Savings and Credit Associations
(ASCAs) and micro-finance institutions (MFIs). They noted that these can be very effective in savings mobilisation credit and can also provide useful links to, and an entry points for formal banking services in rural areas. This would mitigate the lack of credit that small-holder fresh produce farmers agonise for thus making not necessary to relay of merchant market actors.

Revival and reorganisation of cooperatives movement: According to Bernard and Spielman (2009), rural producer organizations (cooperatives) are vital in in supporting smallholder commercialization, and the extent to which principles of an inclusive, bottom-up approach relate to their marketing performance. However, they noted that most of the decisions are made in exclusion of the poor farmers input. This has made the cooperatives or rural producer organizations to look like cartels. Ensuring that small-holder fresh produce farmers participate in decision-making of these organizations would impact positively in ensuring inclusivity and thus relationship building, meeting produce farmer's needs, and ensuring that small-holder fresh produce farmers reap marketing benefits.

Improved productivity: Poulton et al. (2006), argued that broad-based smallholder market participation can only be realized through interventions that raise smallholder production of marketable surpluses through raising 
productivity. This cuts across even the high value sub-sectors such as local market, horticulture and dairy sector. However, eliminating market actors, agents and brokers means eliminating certain financial structures from the farmers. Power asymmetries are as a result of the inability of smallholder's farmers to produce the required volumes for the buyers as well as their lack of market information (Demirbaş, 2005). Although Mather (1999), had argued for the importance of single desk exporter for exporter of fruits as it provided considerable market power over production through state regulations and the control of infrastructure for exports, this is was more appropriate where farmers had commissioned agents rather than merchants market actors especially for consolidation in agro-export marketing strategies. The main disadvantage of commissioners is that they usually do not offer technical assistance or consulting to the producers. Interventions to improve productivity could emanate from reorganisation of the farmers into cooperative movement thus pulling resources, government in provision of subsidised quality inputs, and marketing actors' coordination's or combination of all.

\section{Opening of continental and regional markets: Africa currently has a population of 1.35 billion which is an equivalent to $16.72 \%$ of the total world population. With The African Continental Free Trade Area (AfCFTA) having been ratified by more than 22 countries there is a room for not only regional but a continental market for fresh produce. However for this to materialise, countries need to enact policies that encourage cross border trade. Poulton et al. (2006), argue that there is need to develop efficient local and regional markets for African produce, with harmonised tariffs to ensure cross border trade.}

Contract farming: According to Emongor (2009), those small-scale farmers who are able to supply to supermarkets earned significantly higher income compared to those who supply to the traditional markets. This calls for contract farming. Supermarkets purchases the harvest of independent farmers under certain prenegotiated terms and conditions on price, quantity, quality and inputs. The contract enables the firm to ensure a steady supply of the desired raw materials market while supermarkets have reliable supply for their customers. Roy (1963), defines contract farming as those contractual arrangements between farmers and companies whether oral or written specifying one or more conditions of production and/or marketing of an agricultural product. This definition was considered too broad as it included marketing or forward contract. Contract farming needs to be distinguished from such simple marketing contracts. Little (1994), provide a more comprehensive definition of contract farming. They define it as a "form of vertical coordination between growers and buyer processors that directly shape production decisions through contractually specifying market obligations such as value, volume, quality and at times price, provide specific inputs and exercise some control at the point of production." Thus, contract farming or vertical co-ordination stands between open market and the vertically integrated agribusiness firms. The advocates of contract farming view it as a dynamic partnership between agribusiness companies or small farmers and the supermarkets that benefit both without sacrificing the rights of either. It offers a vehicle for the transfer of technology and the modernisation of peasant small holdings. However, a group negotiated contract farming is more appropriate than individual farmer contracted farming, since it gives small-holder fresh produce farmers an equal say on the contract. Critics of contract farming allege that it would lead to disruption of subsistence production and the inevitable impoverishment of the rural poor. It has been criticised as being a tool for business firm to exploit an unequal power relationship with growers (Key and Runsten, 1999). Clapp (1994), refers to contract farming as a "form of disguised proletarization" as it secures the farmers land and labour while leaving him with the formal title for both. The control exercised by the company is indirect but effective, the "farmer" control is legal but "illusory" making him a "propertied labourer." Contract farming is fundamentally a way of sharing of risk between the supermarkets/ agroprocessors and the farmer, however, the distribution of risk depends heavily on factors like bargaining power, availability of alternatives and access to information. This calls for empowering small-holder fresh produce farmers, to ensure equal platform in contract negotiations. Contract farming as a corporate strategy requires that the farmers remain a source of reliable and inexpensive raw materials thus benefit the supermarkets and agroprocessing firms, while farmers access 
purifiable returns on investments. This is possible if the contract with farmers ensure that they are provided with seeds or fertilisers and transfer of product-specific knowledge. In some cases contracts are signed after the harvest as suppliers do not trust every producer to comply with the conditions. However, a well negotiated contract farming can benefit both the supermarkets, agro-processors as well as fresh produce smallholder's farmers.

Vertical integration: A number of networking strategies can be offered among small-holder fresh produce farmers that allow value addition such as grading, sorting cleaning, freezing processing and packaging, thus value addition before the food reach the retail market. Intermediaries who apply such networking strategies grow their own crops or let them grow through contract farming. Some act in the name of large food trading chains. Downstream input provision as well as extension services is offered to the farmers and upstream function such as or inter-sectoral upgrading and providing of storage and transport facilities and other value additions, development of cold storage required by modern retailing is provided after harvest. The aim is to provide a better product quality and traceability and to increase the shelf life of produce. Service processes, such as cleaning, sorting, packing and labelling of fresh produce are part of this form of functional supplier upgrading. This vertical networking can be handled through cooperative movement or government supported organisation to assist the smallholder fresh producer

\section{Conclusion}

It is evidence from the literature that the over reliance on merchant market actors by smallholder fresh produce farmers results in exploitation as the objectives of the merchant market actors is profit maximisation compared to commissioned market actors who look at the development and sustainability of the fresh produce supply. The individualism of the farmers also help in the exploitation due to lack of the bargain power. It imperative that farmers should reorganise with help of the moderating factors from the government as well commissioned market actors in order to ensure farmers get the right inputs, technology as well as price for the products. This would act as a motivator not only for the current small-holder fresh produce farmers, but also young generation would be inspired to get involved in agribusiness farming rather than seek jobs in the cities and towns due the good return on investments.

\section{REFERENCES}

Antwi M, Seahlodi P (2011). Marketing constraints facing emerging small-scale pig farmers in Gauteng province, South Africa. J. Hum. Ecol. 36(1): 37-42.

Appel A, Franz M, Hassler M (2014). Intermediaries in agrofood networks in Turkey: How middlemen respond to transforming food market structures. DIE ERDE-J. Geographical Soc. Berlin: 145(3): 148-157.

Asliddin A, Suxrob D (2015). Role of agricultural marketing in economic development. Econ. 8(9)

Bernard T, Spielman DJ (2009). Reaching the rural poor through rural producer organizations? A study of agricultural marketing cooperatives in Ethiopia. Food. Pol. 34(1): 60-69.

Bignebat C, Koç AA, Lemeilleur S (2009). Small producers, supermarkets, and the role of intermediaries in Turkey's fresh fruit and vegetable market. Agr. Econ. 40: 807-816.

Brondízio ES, Safar CA, Siqueira AD (2002). The urban market of açaí fruit (Euterpe oleracea Mart.) and rural land use change: ethnographic insights into the role of price and land tenure constraining agricultural choices in the Amazon estuary. Urban Ecosystems, 6(1-2): 67-97.

Chiciudean GO, Arion F, Muresan I (2015). Marketing oriented and sales oriented companies in the agro-food industry. Bul. University. Agr. Sci. Vet. Med. Cluj-Napoca. Horticulture. 72(2): 476-482.

Chiuri W, Birachi E, Buruchara R, Adekunle W, Fatunbi O, Pali PN, Nkonya E (2013). Market access for agroenterprise diversity in the Lake Kivu Pilot Learning Site of the sub-Saharan Africa Challenge Programme. Afr. J. Agric. Resourc. Econ. 8(311-2016-5591): 120-134.

Demirbas $N$ (2005). The effects of the recent legal arrangements concerning the wholesale markets on actors within the fruit-vegetable marketing chain: The case of Izmir, Turkey. J. Appl. Sci. 5(9): 1533-1541.

Diao X, Hazell P, Thurlow J (2010). The role of agriculture in African development. World. Develop. 38(10): 1375-1383.

Duffy DL (2005), "Affiliate marketing and its impact on e-commerce", J. Consum. Marketing. 22(3): 161-163.

Emongor RA (2009). The impact of South African supermarkets on agricultural and industrial development in the Southern African Development Community (Doctoral dissertation, University of Pretoria).

Garcia OA, McGrenra D, Khaira H (2018). Republic of Kenya Smallholder Horticulture Marketing Programme Impact Evaluation.

Hersi M (2020). Our fresh produce farmers need protection from cartels, Wakulima market https://mohammedhersi.com/2020/05/23/

ILO (2019). Africa's employment landscape COUNTRY PROFILES RESOURCEShttps://ilostat.ilo.org/africaschanging-employment-landscape/

Imam YB, Chibok BM, Gamama Y (2014). Channels of distribution of agricultural produce in Nigeria'. Channels. 4(22): 62-66.

Jari B, Fraser G (2009). An analysis of institutional and technical factors influencing agricultural marketing amongst smallholder farmers in the Kat River Valley, Eastern Cape Province, South Africa, Afr. J. Agric. Res. 4(11): 1129-1137. 
Kamau J (2019) How Cartels Have Pushed Up Fertiliser Prices, Making Food Costly, Seeds of Gold, Daily nation, 27 APRIL 2019

Karthikeyan G (2016). Problems in the marketing of agricultural goods. Intl. J. Multidisciplinary. Res. Modern. Educ. 233-235.

Mandal A (2019) Implementing Digital Marketing in Agribusiness: Challenges, Scope and Oppurtunities Passionate Marketer|FMCG/FandB sector| IIMA 2018-20 | NIT Durgapur 2013-17

Mather C (1999). Agro-commodity chains, market power and territory: re-regulating South African citrus exports in the 1990s. Geoforum 30(1): 61-70.

Mburu P (2020), Coming soon in Nairobi - a farmers' market like no other, Seeds of Gold, Daily Nation, Wednesday April 12020

Mittendorf HJ (1989). Improving agricultural physical marketing infrastructure in Africa through more selfhelp. J. Intl. Food. Agribus. Marketing. 1(1): 9-27.

Molony T (2008). Running out of credit: the limitations of mobile telephony in a Tanzanian agricultural marketing system. J. Modern. Afr. Studies. 46(4): 637-658.

Moyo S (2016). Family farming in sub-Saharan Africa: its contribution to agriculture, food security and rural development (No. 150). Working paper.

Mudiwa B (2017). Theories of Smallholder Agribusiness Entrepreneurship in the African Context: A Critical Review. AFRREV IJAH: Intl. J. Arts. Hum. 6(1): 221-236.

Ohashi K (2020). Cartels are Kenya's enemy number one, The standard February 21st 2020

Olwande J, Smale M, Mathenge MK, Place F, Mithöfer D (2015). Agricultural marketing by smallholders in Kenya: A comparison of maize, kale and dairy. Food Pol. 52: 2232.

Poole N (2017). Smallholder agriculture and market participation. Food and Agriculture Organization of the United Nations (FAO).

Poulton C, Kydd J, Dorward A (2006). Overcoming market constraints on pro-poor agricultural growth in Sub-Saharan Afr. Develop. Pol. Rev. 24(3): 243-277.

Ribeiro-Soriano D, Urbano D (2009). Overview of collaborative entrepreneurship: An integrated approach between business decisions and negotiations. Group Decision and Negotiation, 18(5): 419-430.
Rossi M, Vrontis D, Thrassou A (2014). Agro business in a changing competitive environment-Campania firms' strategic, marketing and financial choices. World Rev. Entrep. Manage. Sustain. Develop. 5. 10(2-3): 312-333.

Ruben R, Slingerland MA, Nijhoff GH (2006). Agro-food chains and networks for development: issues, approaches and strategies. In Agro-food supply chains and networks for development: Proceedings of the Frontis Workshop on Agro-food Chains and Networks for Development, Wageningen, The Netherlands, 6-7 September 2004 (No. 14, pp. 1-25). Springer.

Shiferaw B, Obare G, Muricho G (2008). February). Rural market imperfections and the role of institutions in collective action to improve markets for the poor. In Natural Resources Forum 32(1): 25-38. Oxford, UK: Blackwell Publishing Ltd.

Toledano N, Urbano D (2008). Promoting entrepreneurial mindset at universities: A case study in the south of Spain. Eur. J. Intl. Manage. 2(4): 382-99.

Wanzala J (2019). Village gets new lease of life as farmers reap from Sh230m project, standardmedia. 21st Dec 2019 00:00:00 https://www.standardmedia.co.ke/article/2001354014/villa ge-gets-new-lease-of-life-as-farmers-reap-from-sh230mproject 